\title{
Why firms use convertibles: A further test of the sequential-financing hypothesis
}

\author{
Shao-Chi Chang ${ }^{\text {a }}$, Sheng-Syan Chen ${ }^{\text {b,*, }}$, Yichen Liu ${ }^{\text {a }}$ \\ a Institute of International Business, National Cheng Kung University, Tainan 701, Taiwan, ROC \\ ${ }^{\mathrm{b}}$ Department of Finance, College of Management, Yuan Ze University, 135 Yuan-Tung Road, Chung-Li, \\ Taoyuan 320, Taiwan, ROC
}

Received 24 November 2002; accepted 7 February 2003

\begin{abstract}
The sequential-financing hypothesis advanced by Mayers [J. Financ. Econ. 47 (1998) 83] suggests that convertibles are more valuable for issuing firms with focused activities. The hypothesis also suggests that firms may design their convertibles so that there are sufficient internal funds for future investment expenditures so as to avoid the costs of accessing capital markets. This paper provides direct evidence for these two predictions. We find that the stock market responds more favorably to the announcements of convertible offerings by focused firms than to those by diversified firms. This finding holds even after controlling for other potential explanatory variables. We also find that the issuing firms' net new financing is not significantly different from zero over the life of the convertible debt. Thus, our results provide further support for the sequential-financing hypothesis that convertible debt financing is motivated by a desire to minimize security issue costs and agency costs of overinvestment for firms with promising growth opportunities to finance a sequence of potential investment options.

(c) 2003 Elsevier B.V. All rights reserved.
\end{abstract}

JEL classification: G14; G32

Keywords: Convertibles; Sequential-financing hypothesis; Corporate focus; Incremental financing

\section{Introduction}

Convertible debt issues constitute an important source of corporate financing around the world. In particular, growth firms rely heavily on convertibles for new

\footnotetext{
${ }^{*}$ Corresponding author. Tel.: +886-3-4638800x667; fax: +886-3-4354624.

E-mail address: fnschen@saturn.yzu.edu.tw (S.-S. Chen).
} 
capital. However, why firms use convertible debt remains unresolved. Previous research has provided several possible explanations. Using convertible debt financing may mitigate the Jensen and Meckling's (1976) asset substitution problem and the Myers' (1977) underinvestment problem (Green, 1984; Jen et al., 1997). Convertible debt financing also helps resolve the disagreement between managers and debtholders regarding estimating the risk of a firm's activities (Brennan and Kraus, 1987; Brennan and Schwartz, 1988), and it may be used as an indirect way of equity financing when adverse-selection problems make a conventional stock issue unattractive (Stein, 1992).

Recently, Mayers (1998) provides another rationale for using convertibles. Mayers argues that a convertible debt plays a key role in financing a firm's long-term strategic investments due to its unique function in matching cash inflows with expected investment outlays. Specifically, Mayers demonstrates that convertibles are the most cost-effective way for firms with promising growth opportunities to finance a sequence of potential investment options of uncertain value and timing since, under certain conditions, convertibles simultaneously reduce security issue costs as well as agency costs of overinvestment. The convertibles economize on issue costs since conversion leaves funds inside the firms and reduces leverage when an investment option is valuable. They also control the overinvestment problem by returning the funds to bondholders through redemption when the investment option is not valuable.

The distinguishing feature of Mayers' sequential-financing hypothesis is that the call provision, a common feature of convertibles, allows the firms to proceed with their financing plans by forcing conversion when the investment option is valuable. Thus, evidence of investment and investment-related activity (i.e. financing) timed with bond conversions would support the sequential-financing hypothesis. Mayers backs the hypothesis by documenting significant increases in capital expenditures and new long-term debt financing starting in the year of the call. Such evidence supports the conclusion that convertible conversions are designed to aid in the future financing of valuable real investment options.

For convertible debt to function well as a control device as described in Mayers' model, the correlation between the values of the firm's investment projects at each investment stage is very important. As suggested by Mayers, convertibles are more useful in reducing security issue costs and controlling the overinvestment problem when values of the initial project and the future investment option have a strong positive correlation, a feature generally found in firms with focused activities. Consequently, the sequential-financing hypothesis predicts that convertibles are more valuable for focused firms. The sequential-financing hypothesis also suggests that firms may design the convertibles so that there are sufficient internal funds for future investment expenditures in order to avoid the costs of accessing capital markets. If the Mayers model is correct, then the sequential-financing hypothesis predicts that the issuing firm's net new financing will not be positive over the life of the convertible bonds.

These two predictions, however, have not been directly tested in the literature. The purpose of this study is to provide direct evidence for these predictions. The first 
prediction will be tested through the investigation of the stock market's reaction to announcements of convertible issues. To the extent that the capital market is persuaded that convertibles are a cost-effective way for firms with promising growth opportunities to finance a sequence of potential investment options, it is likely to respond more favorably to announcements of convertible debt offerings by focused firms. The second prediction will be tested by examining the issuing firms' net new financing from the issuance of convertible bonds to their maturity or forced conversion. ${ }^{1}$

To explore the sequential-financing hypothesis, we have investigated a sample of Taiwanese-listed firms that announced public offerings of convertible debt during the period 1990-1999. Much of the existing literature on convertibles focuses on data from developed countries, and thus may reflect the specific environment in those countries. Very little is known about convertibles in emerging markets. To further the research, this paper intends to help fill this gap by providing international evidence on the stock market's reaction to announcements of convertible issues by Taiwanese firms. Taiwan represents one of the fastest-growing economies among the Pacific Rim countries and also attracts substantial investments from American, British, and other multinational firms. Thus, this study provides useful insights into the determinants of the stock market response to announcements of convertible issues by firms in high-growth economies. By way of comparison, our sample firms have, on average, better growth opportunities than US convertible-issuing firms. Therefore, the use of Taiwanese data in this study helps investigate the sequential-financing hypothesis since the cost-controlling function of convertibles is particularly valuable for growth firms with uncertain future investment options.

Our results show that announcements of convertible debt offerings by Taiwanese firms are, on average, associated with significantly positive abnormal returns. These results are similar to those for Japan (e.g. see Kang and Stulz, 1996), but different from those for the US and UK which show a significantly negative stock market reaction to announcements of convertibles (e.g. see Dann and Mikkelson, 1984; Eckbo, 1986; Mikkelson and Partch, 1986; Hansen and Crutchley, 1990; Kim and Stulz, 1992; Davidson et al., 1995; Jen et al., 1997; Abhyankar and Dunning, 1999). ${ }^{2}$ We also find that the stock market responds more favorably to the announcements of convertible offerings by focused firms than to those by diversified firms. This finding holds even after controlling for other potential explanatory variables. We also demonstrate that the issuing firms' net new financing is not significantly different from zero over the life of the convertible debt. Our results, together with the empirical evidence documented by Mayers (1998), suggest that convertible debt financing is motivated by a desire to minimize security issue costs and agency costs of overinvestment for firms with promising growth opportunities to finance a sequence of major corporate investments of uncertain value and timing.

\footnotetext{
${ }^{1}$ Net new financing is defined as new long-term debt and equity capital minus refinancing of existing long-term debt.

${ }^{2}$ De Roon and Veld (1998) find that announcements of convertibles for the Dutch market are, on average, associated with insignificantly positive abnormal returns.
} 
The remainder of this paper is organized as follows. Section 2 discusses the sequential-financing hypothesis. Section 3 provides the sample selection and description. Section 4 examines the stock market's reaction to announcements of convertible issues. Section 5 provides evidence on the issuing firms' net new financing prior to maturity or forced conversion of convertibles. The final section concludes.

\section{The sequential-financing hypothesis}

The sequential-financing hypothesis advanced by Mayers (1998) suggests that convertibles are a cost-effective way of financing for firms with promising investment opportunities. Managers of growth firms face the challenge of designing a financing strategy that minimizes the costs associated with funding not only the current projects but also the expected sequence of investment options that also require funds if they are later proven to be profitable. In Mayers' two-period model, three debt financing choices are available: sequentially issuing single-period straight debt, issuing two-period straight debt, and issuing a convertible bond. ${ }^{3}$ The problem for sequentially issuing single-period straight debt is that additional issuing costs of new security offerings arise when the investment option matures into being valuable. ${ }^{4}$ To economize on issue costs, firms could alternatively issue two-period straight debt to raise enough funds up front for both the current project and the investment option. This financing choice, however, could result in the overinvestment (free-cashflow) problem discussed by Jensen (1986), since a second-period project will be financed, regardless of whether the investment option turns out to be valuable or not. 5

The use of convertible debt financing would be the optimal solution to solve this sequential-financing problem by both economizing on the issue costs and controlling the overinvestment problem. If the investment option turns out to be valuable, then convertible bonds would be converted into equity, leaving funds within the firm for new investments and thus economizing on second-period issue costs. On the other hand, if the investment option turns out not to be valuable, then no conversion occurs, and the funds are returned to bondholders through redemption, thus controlling the agency costs of overinvestment. Therefore, convertible debt financing enables management to match capital inflows with expected investment outlays.

For convertibles to function well as a control device as described in Mayers' model, however, the correlation between the values of the firm's investment projects at each investment stage is important. Because the conversion value is influenced by both the outcome of the initial investment and the value of the investment option, there exists the possibility that the moneyness of the conversion value does not match the profitability of the investment option. For instance, even though the investment option

\footnotetext{
${ }^{3}$ Equity financing is not considered, because of its high information (dilution) costs.

${ }^{4}$ The issuing costs include both transaction costs and information costs.

5 Jensen (1986) argues that self-interested managers have incentives to misuse free-cash-flow in valuedecreasing investments rather than distributing it to shareholders.
} 
turns out to be unattractive, convertible debtholders will still convert rather than accept redemption if the bond is in the money. In this case, convertible debt financing fails to control the overinvestment problem. Similarly, if the bond is out of the money and the investment option turns out to be attractive, then additional security issue costs are needed and hence, convertible debt financing does not economize on issue costs.

Therefore, convertible debt financing will perform better in reducing security issue costs and controlling the overinvestment problem when values of the initial project and the future investment option have a strong positive correlation, a feature generally found in firms with focused (less diversified and hence more volatile) activities. The sequential-financing hypothesis thus predicts that convertibles create more value for issuing firms with focused activities. Mayers (1998) does not offer a direct test of this hypothesis, but discusses the indirect evidence documented by Essig (1991) whereby the volatility of the firm's cash flow is positively related to the firm's propensity to employ convertibles. Our study aims to provide direct evidence for this prediction through the investigation of the stock market's reaction to announcements of convertible issues. To the extent that the capital market is persuaded that convertibles are a cost-effective way for firms with promising growth opportunities to solve the sequential-financing problem, it is likely to respond more favorably to announcements of convertible debt financings by firms with focused activities.

The sequential-financing hypothesis also suggests that the issuing firms' net new financing will not be positive over the life of the convertible bonds. The Mayers story is one where the firms want to avoid the costs of accessing capital markets when capital needs are high. Therefore, if Mayers' model is correct, then firms should design the convertibles so that there are sufficient internal funds to satisfy the new investment expenditures. Our study also aims to provide direct evidence for this prediction through the investigation of the issuing firms' net new financing prior to the maturity or forced conversion of convertible bonds.

\section{Sample selection and description}

The results of this study are based on a sample of Taiwanese-listed firms that have announced public offerings of convertible debt financing during the period from 1990 to 1999. The announcements have been collected from the Securities and Futures Institute Database (SFID) and the Excellent Business Database (EBD), which provide news-service abstracts from major Taiwanese journals and magazines. ${ }^{6}$ When a repeat announcement is found in a different publication, the announcement that has the earliest date is chosen, because this is the earliest date when the information about the convertible debt issues by Taiwanese firms was publicly available. Our definition

\footnotetext{
${ }^{6}$ SFID provides a broader coverage of corporate announcements than does EBD. However, the earliest year for data to be available in SFID starts in 1997. Consequently, we have to rely on EBD for announcements earlier than 1997.
} 
of announcement date (day 0) is the date of the publication in which the company's initial announcement appeared.

We include the initial announcements of convertible debt offerings if data on the issuing firms and convertible securities are available from SFID and the Taiwan Economic Journal (TEJ) Data Bank. Our sample comprises 109 announcements by 86 different Taiwanese firms. All the convertible bonds in the sample are callable. Table 1 reports a distribution of our sample by time profile, industry classification, and call protection period (CPP). There is some clustering of announcements during 1997 1999. On a daily basis, however, the announcements are non-contemporaneous. The convertible offerings are distributed over a wide range of industries: fourteen 2-digit Standard Industrial Classification (SIC) codes are represented. ${ }^{7}$ Firms in the electronics and construction industries represent about $60 \%$ of the announcements in the sample. Some concentration among specific industries is expected since neither the distribution of investment opportunities nor their valuation should be random across industries.

Table 1 also shows that most of the convertible bonds in our sample have a short protection period. ${ }^{8}$ About $90 \%$ of the issues are first callable within 2 years of the issue date and all of the issues are first callable within 3 years of the issue date. The average (median) time to first call for our sample is 1.3 years ( 1 year), shorter than the average (median) time to first call of 2.1 years (2 years) for US convertible issues as reported in Lewis et al. (1998). The short CPP in our sample is consistent with Mayers' (1998) hypothesis since the firms' demand for sequential-financing should result in conversions over a short time frame.

We have also investigated the call provisions of the convertible issues in our sample. We find that even after the CPP, the issuing firms are still not allowed to call their convertible issues unless their share price exceeds the conversion price by a certain percentage (usually 50\%) for a certain period of time (usually 30 consecutive trading days). This additional condition would make the conversion-forced calls of convertible debt more likely to occur when the investment opportunities are profitable. This is also consistent with Mayers' (1998) model since it views convertibles as a cost-effective way for firms with promising growth opportunities to finance a sequence of potential investment options.

Table 2 reports the information on several explanatory variables used in this study. Data are obtained from SFID and TEJ. The number of observations varies because of data availability. Our primary measure of corporate focus is based on the number of business segments reported in the firms' annual financial reports. Our sample firms have two business segments on average and one business segment at the median. The average level of corporate focus for our sample firms is close to that for US firms as reported in Comment and Jarrell (1995).

\footnotetext{
${ }^{7}$ The industry classification obtained from TEJ is based on that used by the Taiwan Stock Exchange (TSE). Totally, there are 21 2-digit SIC codes used by the TSE.

${ }^{8}$ Data on CPPs for convertible bond issues are obtained from the issuing firms' financial statements.
} 
Table 1

Sample distribution of announcements of convertible debt offerings by Taiwanese firms

\begin{tabular}{|c|c|c|}
\hline Year & Number & $\%$ \\
\hline \multicolumn{3}{|c|}{ Panel A: Sample distribution by year } \\
\hline 1990 & 4 & 3.7 \\
\hline 1991 & 3 & 2.8 \\
\hline 1992 & 1 & 0.9 \\
\hline 1993 & 1 & 0.9 \\
\hline 1994 & 7 & 6.4 \\
\hline 1995 & 0 & 0.0 \\
\hline 1996 & 4 & 3.7 \\
\hline 1997 & 41 & 37.6 \\
\hline 1998 & 36 & 33.0 \\
\hline 1999 & 12 & 11.0 \\
\hline Total & 109 & 100.0 \\
\hline \multicolumn{3}{|l|}{ Industry } \\
\hline \multicolumn{3}{|c|}{ Panel B: Sample distribution by industry } \\
\hline Food & 2 & 1.8 \\
\hline Plastic & 3 & 2.8 \\
\hline Textile & 5 & 4.6 \\
\hline Electrical & 6 & 5.5 \\
\hline Wire and cable & 5 & 4.6 \\
\hline Chemicals & 4 & 3.7 \\
\hline Paper & 2 & 1.8 \\
\hline Steel & 8 & 7.3 \\
\hline Rubber & 1 & 0.9 \\
\hline Automobile & 2 & 1.8 \\
\hline Electronics & 48 & 44.0 \\
\hline Construction & 17 & 15.6 \\
\hline Transportation & 4 & 3.7 \\
\hline Others & 2 & 1.8 \\
\hline Total & 109 & 100.0 \\
\hline \multicolumn{3}{|l|}{$\mathrm{CPP}$} \\
\hline \multicolumn{3}{|c|}{ Panel C: Sample distribution by CPP } \\
\hline $\mathrm{CPP} \leqslant 1$ year & 65 & 59.6 \\
\hline 1 year $<\mathrm{CPP} \leqslant 2$ years & 33 & 30.3 \\
\hline 2 years $<\mathrm{CPP} \leqslant 3$ years & 11 & 10.1 \\
\hline Total & 109 & 100.0 \\
\hline
\end{tabular}

Notes: This table summarizes the sample distribution of announcements of convertible debt offerings by year, industry, and CPP. There are a total of 86 Taiwanese firms involved in 109 convertible debt issues from 1990 to 1999. The announcements were collected from the SFID and the EBD, which provide newsservice abstracts from major Taiwanese journals and magazines. The industry classification obtained from the TEJ Data Bank is based on that used by the TSE. Data on CPPs for convertible bond issues are obtained from the issuing firms' financial statements.

In addition to corporate focus, we also use data on Tobin's $q$, debt ratio, volatility of earnings, firm size, relative size of issue, runup, and the conversion premium ratio 
Table 2

Sample characteristics

\begin{tabular}{lcccc}
\hline Variables & $N$ & Mean & Median & Standard deviation \\
\hline Number of business segments & 109 & 2.02 & 1.00 & 1.67 \\
Tobin's $q$ & 109 & 1.89 & 1.76 & 0.55 \\
Debt ratio (\%) & 109 & 10.17 & 8.10 & 9.27 \\
Volatility of earnings & 106 & 0.036 & 0.030 & 0.026 \\
Firm size (US\$ million) & 109 & 896 & 545 & 995 \\
Relative size of issue (\%) & 109 & 14.79 & 14.00 & 7.76 \\
Runup (\%) & 109 & -0.39 & 0.37 & 13.97 \\
Conversion premium ratio & 80 & 1.05 & 1.01 & 0.07 \\
\hline
\end{tabular}

Notes: The sample consists of 109 announcements of convertible bond issues by 86 Taiwanese firms from 1990 to 1999. Data were obtained from the SFID and the TEJ Data Bank. Tobin's $q$ is estimated as the average ratio of the market value of the firm's assets to the book value of the firm's assets for the three fiscal years before the announcement, where the market value of assets is estimated as the book value of assets minus the book value of common equity plus the market value of common equity. Debt ratio is long-term debt divided by book value of total assets for the year preceding the announcement. Volatility of earnings is the standard deviation of the announcing firm's earnings before interest and tax divided by total assets over the 5 years preceding the announcement. Firm size is the announcing firm's market value of assets for the year preceding the announcement. The relative size of the issue is the total amount of a convertible debt issue divided by the market capitalization of the issuing firm for the year preceding the announcement. Runup is the 29-day cumulative abnormal returns from 30 to 2 days preceding the announcement. Conversion premium ratio is conversion price divided by the market price of the underlying common stock, measured by the 30 -day average closing price preceding the issue-approval date. The number of observations varies, because of data availability.

for our sample firms. Tobin's $q$ has been widely used to distinguish firms with good investment opportunities from those with poor investment opportunities. ${ }^{9,10}$ The theoretical Tobin's $q$ is defined as the ratio of a firm's market value to the replacement costs of its assets. Because of data availability, we estimate $q$ as the ratio of the market value of the firm's assets to the book value of the firm's assets, where the market value of assets equals the book value of assets minus the book value of common equity plus the market value of common equity. This simple measure

\footnotetext{
${ }^{9}$ See, for example, Lang et al. (1989, 1991), Howe et al. (1992), Doukas (1995), Kang and Stulz (1996), Chen and Ho (1997), Abhyankar and Dunning (1999), Lewis et al. (1999), and Chen et al. (2000).

${ }^{10}$ To empirically distinguish the effects of investment opportunities, a proxy for the profitability of new investment is needed. Tobin's $q$ is perhaps the most commonly used measure of growth opportunities (Denis, 1994). The deviation of market value from replacement value will depend on the profitability of both the firm's assets in place and its expected investment opportunities. With scale-expanding investments and decreasing marginal returns on capital, if new investment opportunities are expected to be profitable, then the firm's assets in place must also be profitable and Tobin's $q$ will be high (Lang and Litzenberger, 1989). On the other hand, if the profitability of the firm's assets in place is low, then its investment opportunities will also be expected to earn a low rate of return and Tobin's $q$ will be low. Therefore, Tobin's $q$ will be positively correlated with the profitability of new investment. Note that there is no necessary connection between the $q$ ratio and the marginal profitability of new investment opportunities. However, it seems reasonable to follow Barclay and Litzenberger (1988) and Lang and Litzenberger (1989) and assume that, on average, a measure of a firm's average profitability of investment is positively correlated with the marginal profitability of new investment.
} 
of $q$ for investment opportunities (the "pseudo $q$ ") has been widely used in previous studies. ${ }^{11}$ Our pseudo $q$ variable is the average pseudo $q$ for the three fiscal years prior to the announcement. ${ }^{12}$ The mean (median) $q$ of our sample firms is 1.89 (1.76). Lewis et al. (1999) report a mean (median) $q$ of 1.58 (1.33) for their sample of US firms announcing convertible debt financing. Thus, this suggests that our sample firms have, on average, better investment opportunities than the sample of US convertible-issuing firms.

Following Mayers (1998) and Lewis et al. (1999), the debt ratio is measured by long-term debt divided by the book value of total assets for the year preceding the announcement. Volatility of earnings is the standard deviation of the announcing firm's earnings before interest and tax divided by total assets over the 5 years preceding the announcement (as in Jen et al., 1997). Firm size is the announcing firm's market value of assets for the year preceding the announcement. Similar to Dann and Mikkelson (1984) and others, the relative size of issue is the total amount of a convertible debt issue divided by the market capitalization of the issuing firm for the year preceding the announcement. Runup is the 29-day cumulative abnormal returns from 30 to 2 days preceding the announcement (as in Jen et al., 1997). ${ }^{13}$ Finally, similar to Dann and Mikkelson (1984), the conversion premium ratio is defined as the ratio of conversion price at announcement to the 30-day average of underlying stock prices before the official issue-approval date. ${ }^{14}$

\section{Stock markets reaction to announcements of convertible issues}

\subsection{Overall sample}

We employ standard event-study methods to examine stock price responses to announcements of convertible debt offerings, with data obtained from TEJ. The abnormal return is calculated as the difference between the actual return and an expected return generated by the market model. Market model parameters are estimated over

\footnotetext{
${ }^{11}$ See, for example, Denis (1994), Perfect and Wiles (1994), Barclay and Smith (1995a,b), Agrawal and Knoeber (1996), Kang and Stulz (1996), Chen and Ho (1997), Abhyankar and Dunning (1999), Holderness et al. (1999), Lewis et al. (1999), and Chen et al. (2000). Chung and Pruitt (1994) show that at least $96.6 \%$ of the variability of Tobin's $q$ (based on Lindenberg and Ross, 1981) is explained by this simple measure of $q$.

${ }^{12}$ This follows the approach used in Lang et al. (1991), Chen and Ho (1997), and Chen et al. (2000). A three-year average gives a better estimate of a firm's true $q$ (Lang et al., 1989). Our conclusions in this paper remain unchanged if the pseudo $q$ variable over the last year prior to the announcement is used.

${ }_{13}$ Our calculation of abnormal returns is described below.

${ }^{14}$ Unlike Dann and Mikkelson (1984) who use the stock price at a specific date in deriving the conversion premium ratio, we use the average stock prices during the 30-day pre-offer period, because Taiwan's stock market is generally regarded as more volatile relative to the US stock market. Many of our sample firms reported conversion premium ratios based on this measure in their financial statements. The mean (median) conversion premium ratio for our sample firms is 1.05 (1.01), which is close to that for US firms announcing public offerings of convertible debt (Dann and Mikkelson, 1984).
} 
Table 3

Cumulative abnormal returns

\begin{tabular}{llll}
\hline $\begin{array}{l}\text { Period relative to the } \\
\text { announcement }\end{array}$ & $\begin{array}{l}\text { Mean abnormal return } \\
(\%)\end{array}$ & $t$-Statistic & $\begin{array}{l}\text { Proportion of positive } \\
\text { abnormal returns (\%) }\end{array}$ \\
\hline$[-30,-2]$ & -0.39 & -0.29 & 51 \\
{$[-20,-2]$} & 0.53 & 0.51 & 51 \\
{$[-10,-2]$} & 0.84 & 1.17 & 47 \\
-1 & 0.17 & 0.80 & 53 \\
0 & 0.25 & $2.42^{* *}$ & 50 \\
1 & 0.42 & $2.10^{* *}$ & 50 \\
{$[-1,0]$} & 0.42 & 1.42 & 49 \\
{$[-1,1]$} & 0.83 & $2.02^{* *}$ & 55 \\
{$[2,10]$} & -0.03 & -0.05 & 47 \\
{$[2,20]$} & 0.11 & 0.10 & 46 \\
{$[2,30]$} & -0.59 & -0.47 & 43 \\
\hline
\end{tabular}

Notes: The sample consists of 109 announcements of convertible debt offerings by 86 Taiwanese firms from 1990 to 1999. Cumulative abnormal returns are estimated using the standard market model procedure with the parameters estimated for the period 200 days to 61 days before the announcement. Day 0 in event time is the date of the publication in which the company's initial announcement appears.

“**” represents a $5 \%$ significance level using a two-tailed test.

a period from 200 to 61 days before the initial announcements. The value-weighted Taiwan Stock Exchange All-Share Index is used to measure market return.

Following Kang and Stulz (1996) and De Roon and Veld (1998), we examine the cumulative average abnormal return for the 3-day announcement period (days -1 to +1 ). Though the announcement-period comprising the day of announcement and the day before is the one researchers typically focus on for US studies, this study pays attention to the period that also includes the day after the announcement. Including this additional day eliminates some of the microstructure effects that could arise due to order flow imbalances on the day of the announcement and because of the existence of price limits (Kang and Stulz, 1996). The results of the event-study for the entire sample are reported in Table 3.

The evidence shows that our sample firms experience significantly positive abnormal returns for the day of announcement, for the day after the announcement and for the $[-1,1] 3$-day announcement-period. The average $[-1,1]$ announcementperiod abnormal return of our sample firms is $0.83 \%$, significant at the $5 \%$ level using a two-tailed test, and $55 \%$ of the sample announcement effects are positive. ${ }^{15}$ The average $[-1,0] 2$-day announcement-period abnormal return is also positive, but it is not statistically significant, probably due to the microstructure effects as mentioned above. No significant abnormal returns are observed preceding and following the announcement-period. Our results are similar to those for Japan (Kang and Stulz, 1996), but different from those for the US and UK which show a significantly negative stock market reaction (Dann and Mikkelson, 1984; Eckbo, 1986;

\footnotetext{
${ }^{15}$ We have also conducted significance tests in Table 3 using the $z$-statistic, as described in Dodd and Warner (1983). Similar results are obtained.
} 
Mikkelson and Partch, 1986; Hansen and Crutchley, 1990; Kim and Stulz, 1992; Davidson et al., 1995; Jen et al., 1997; Abhyankar and Dunning, 1999).

Our positive average announcement effect could be attributed to the deregulation of Taiwan's bond market in the 1990s. Taiwanese firms were not allowed to issue convertible bonds until 1990. Therefore, a firm's first convertible issue after it becomes eligible may convey positive information to the market that a firm has promising prospects. Long-term shareholders may allow firms to access capital markets, after they become eligible, only if their prospects are good enough that close monitoring of their actions through banks is no longer necessary (Hoshi et al., 1993; Kang and Stulz, 1996). Since in our sample period about $78 \%$ of the sample firms were allowed, for the first time, to issue convertibles, our average announcement-period abnormal return is significantly positive.

Although not reported, we have also examined abnormal returns for firms that already have convertible debt and firms for which the convertible debt issue appears to be their first one. The mean abnormal return for the first-issue subsample is $1.29 \%$, statistically significant at the $1 \%$ level. In contrast, firms that already have convertible debt experience an insignificant mean abnormal return of $-0.78 \%$. The mean difference between the abnormal returns for both groups of issues is statistically significant at the 5\% level using a two-tailed test. This result is robust to possible deviations from non-normality, since it also holds for the non-parametric KruskalWallis test statistic. Therefore, consistent with the evidence for Japanese firms (Kang and Stulz, 1996), deregulation could possibly explain the positive average announcement effect for Taiwanese firms.

\subsection{Analysis of subsamples based on corporate focus}

To test the sequential-financing hypothesis, the sample is divided into two subsamples based on the degree of corporate focus. In Panel A, Table 4, focused firms are defined as firms with a single business segment while diversified firms are those with multiple business segments (as in Berger and Ofek, 1995; Comment and Jarrell, 1995; Denis et al., 1997; Rose and Shepard, 1997; Anderson et al., 2000). Of the 109 announcements of convertible debt offerings in our sample, 68 were made by issuing firms with a single business segment and 41 were made by those with multiple segments.

Panel A, Table 4, shows that focused firms have a significantly positive average (median) announcement-period abnormal return of $1.52 \%(1.09 \%)$. In contrast, the average and median abnormal returns for the diversified firms are negative, although they are not statistically significant. The mean difference between the abnormal returns for focused and diversified firms is statistically significant at the $5 \%$ level using a two-tailed test. This result is robust to possible deviations from non-normality, since it also holds for the non-parametric Kruskal-Wallis test statistic. These findings are consistent with the prediction by the sequential-financing hypothesis that convertibles are more valuable for issuing firms with focused activities than for those with less-focused activities. 
Table 4

Mean and median announcement-period abnormal returns for subsamples stratified according to corporate focus

\begin{tabular}{llc}
\hline Focused & Diversified & Mean difference \\
\hline Panel A: Firms with a single business segment are considered to be focused firms & \\
Mean abnormal return $=1.52 \%$ & Mean abnormal return $=-0.31 \%$ & $1.84 \%$ \\
Median abnormal return $=1.09 \%$ & Median abnormal return $=-0.30 \%$ & $(2.19)^{* *}$ \\
$\left(2.58^{* *}, 0.04,68\right)$ & $(-0.68,0.50,41)$ & {$[0.08]$} \\
& & \\
Panel B: Firms with more than $75 \%$ of revenue coming from a single business segment are considered to be \\
focused firms & & \\
Mean abnormal return $=1.53 \%$ & Mean abnormal return $=-1.17 \%$ & $2.70 \%$ \\
Median abnormal return $=1.19 \%$ & Median abnormal return $=-1.29 \%$ & $(3.53)^{* * *}$ \\
$\left(2.98^{* * *}, 0.01,79\right)$ & $(-2.07 * *, 0.04,26)$ & {$[0.01]$}
\end{tabular}

Notes: Three-day $(-1,1)$ announcement-period abnormal returns are estimated using the standard market model procedure with the parameters estimated for the period 200 days to 61 days before the announcement. In Panel A, focused firms are firms with a single business segment while diversified firms are those with multiple segments. In Panel B, focused firms are firms with more than $75 \%$ of revenue coming from a single business segment. For each cell, we report the mean abnormal return, the median abnormal return, and, in parentheses, the $t$-statistics, the $p$-value for the Wilcoxon $z$-statistics and the number of observations. For the comparison of means, we report mean difference, the $t$-statistics in parentheses assuming equal variances and the $p$-value for the non-parametric Kruskal-Wallis statistics in square brackets. The results are similar with the assumption of unequal variances.

"***" and "**" represent $1 \%$ and $5 \%$ significance levels using a two-tailed test, respectively. The sample in Panel B is smaller, because of limited data availability.

In Panel B, Table 4, focused firms are defined as firms with more than $75 \%$ of sales coming from a single business segment. ${ }^{16}$ Under this alternative measure of corporate focus, 79 announcements of convertible debt offerings were made by focused firms and 26 were made by diversified firms. ${ }^{17}$ The results in Panel B, Table 4, are generally similar to those in Panel A, Table 4: Convertible debt financing creates more value for focused firms than for less-focused firms.

\subsection{Cross-sectional regression analyses}

Table 5 presents cross-sectional regression analyses of the announcement-period abnormal returns for our sample. The $t$-values reported are computed with heteroskedasticity-consistent standard errors (White, 1980). ${ }^{18}$ Following Berger and Ofek (1995), Comment and Jarrell (1995), Denis et al. (1997), Rose and Shepard (1997),

\footnotetext{
${ }^{16} \mathrm{We}$ appreciate one anonymous referee for a helpful suggestion of this alternative measure of corporate focus.

${ }^{17}$ The sample in Panel B, Table 4, is smaller than that in Panel A, Table 4, because of limited data availability.

${ }^{18}$ The results are similar if we reestimate the regressions using weighted least squares, with the weights equal to the reciprocal of the standard deviation of the market model residual, an approach used in Lang et al. (1991).
} 
and Anderson et al. (2000), we use a dummy variable for corporate focus which is equal to one for focused firms (i.e. those with a single business segment) and zero for diversified firms (i.e. those with multiple business segments).

Model 1 includes the corporate focus dummy as the only explanatory variable. We find that the coefficient for the focus dummy is positive and statistically significant at the $5 \%$ level. That is, the announcement effect is more favorable for the focused firms than for the diversified firms. This finding supports Mayers' sequential-financing hypothesis that convertibles are more valuable for issuing firms with focused activities than for those with less-focused activities. The results in model 1 are consistent with those of Panel A, Table 4.

To test the robustness of our results, we also replace the corporate focus dummy by the following three alternative measures of corporate focus: (1) dummy equal to one for firms with more than $75 \%$ of sales coming from a single business segment; (2) the number of business segments; and (3) a revenue-based Herfindahl index, calculated as the sum of the squares of each segment's revenue as a proportion of total revenue. ${ }^{19}$ The results are reported in models $2-4$. As seen from Table 5, our results are robust for various measures of corporate focus. The coefficient for the number of business segments is significantly negative, while the coefficients for the other two alternative measures of corporate focus are significantly positive. That is, the stock market responds more favorably to the announcements of convertible offerings by firms with focused activities. Our results in model 2 are consistent with those of Panel B, Table 4.

The analysis so far does not control for other potential determinants of the stock price reaction to the announcements of convertible debt issues. Previous research, however, suggests that several other variables could affect the announcement-period abnormal returns of convertible debt offerings. In Table 5, we also estimate multivariate regressions controlling for these variables. As suggested by Stein's (1992) backdoor-equity hypothesis, convertible debt financing is more valuable for firms with high-growth opportunities and limited additional debt capacity (or, alternatively, high expected costs of financial distress). Jen et al. (1997) and Lewis et al. (1999) examine stock price responses to announcements of convertible debt offerings by US firms and find support for the backdoor-equity hypothesis. We use Tobin's $q$ here to measure a firm's investment opportunities. High- $q$ firms are regarded as firms with good investment opportunities. Since firms with high financial leverage and operational risk are expected to have a large expected cost of financial distress, we measure financial leverage and operational risk by the debt ratio and volatility of earnings, respectively (as in Jen et al., 1997). We expect market reaction to be positively related to all of the above three variables.

\footnotetext{
${ }^{19}$ Similar results are obtained if we use an asset-based Herfindahl index, computed in the same way using the book value of identifiable assets of the segment. A revenue-based (an asset-based) Herfindahl index reflects the degree to which sales (assets) are concentrated in just a few of the firm's business segments. Thus, the closer the revenue-based (asset-based) Herfindahl index is to one, the more the firm's sales (assets) are concentrated within a few of its segments.
} 
Table 5

Cross-sectional regression analyses of announcement-period abnormal returns

\begin{tabular}{|c|c|c|c|c|c|c|c|}
\hline \multirow[t]{2}{*}{ Variable } & \multicolumn{7}{|l|}{ Model } \\
\hline & 1 & 2 & 3 & 4 & 5 & 6 & 7 \\
\hline Intercept & $\begin{array}{l}-0.0031 \\
(-0.69)\end{array}$ & $\begin{array}{l}-0.0101 \\
(-2.04)^{* *}\end{array}$ & $\begin{array}{c}0.0175 \\
(2.66)^{* * *}\end{array}$ & $\begin{array}{l}-0.0215 \\
(-2.35)^{* *}\end{array}$ & $\begin{array}{l}-0.0382 \\
(-0.34)\end{array}$ & $\begin{array}{l}-0.0780 \\
(-0.98)\end{array}$ & $\begin{array}{l}-0.0601 \\
(-0.49)\end{array}$ \\
\hline $\begin{array}{l}\text { Dummy equal to one for single- } \\
\text { segment firms }\end{array}$ & $\begin{array}{c}0.0183 \\
(2.49)^{* *}\end{array}$ & & & & & & \\
\hline $\begin{array}{l}\text { Dummy equal to one for firms with } \\
\text { more than } 75 \% \text { of revenue coming } \\
\text { from a single-segment }\end{array}$ & & $\begin{array}{c}0.0255 \\
(3.58)^{* * *}\end{array}$ & & & & & \\
\hline Number of segments & & & $\begin{array}{l}-0.0046 \\
(-7.91)^{* * *}\end{array}$ & & & & \\
\hline Revenue-based & & & & 0.0363 & 0.0375 & 0.0393 & 0.0400 \\
\hline Herfindahl Index & & & & $(2.92)^{* * *}$ & $(2.79)^{* * *}$ & $(2.62)^{* *}$ & $(2.31)^{* *}$ \\
\hline Tobin’s $q$ & & & & & $\begin{array}{c}0.0138 \\
(1.85)^{*}\end{array}$ & & $\begin{array}{l}0.0235 \\
(1.94)^{*}\end{array}$ \\
\hline Debt ratio & & & & & $\begin{array}{c}0.1317 \\
(2.59)^{* *}\end{array}$ & & $\begin{array}{l}0.1497 \\
(2.61)^{* *}\end{array}$ \\
\hline Volatility of earnings & & & & & $\begin{array}{l}-0.0088 \\
(-0.07)\end{array}$ & & $\begin{array}{l}-0.0076 \\
(-0.04)\end{array}$ \\
\hline Log of firm size & & & & & $\begin{array}{l}-0.0016 \\
(-0.25)\end{array}$ & & $\begin{array}{l}-0.0016 \\
(-0.19)\end{array}$ \\
\hline Relative size of issue & & & & & $\begin{array}{l}0.0234 \\
(0.40)\end{array}$ & & $\begin{array}{l}0.0022 \\
(0.03)\end{array}$ \\
\hline Runup & & & & & $\begin{array}{l}-0.0002 \\
(-0.27)\end{array}$ & & $\begin{array}{l}-0.0003 \\
(-0.58)\end{array}$ \\
\hline
\end{tabular}




\begin{tabular}{|c|c|c|c|c|c|c|}
\hline & & & & & $\begin{array}{c}0.0044 \\
(0.37) \\
0.0004 \\
(0.50) \\
0.0090 \\
(0.83) \\
0.0024 \\
(0.26)\end{array}$ & $\begin{array}{c}0.0030 \\
(0.23) \\
-0.0001 \\
(-0.14) \\
0.0117 \\
(0.98) \\
0.0010 \\
(0.11)\end{array}$ \\
\hline 0.034 & 0.062 & 0.022 & 0.042 & 0.055 & 0.007 & 0.056 \\
\hline $4.77 * *$ & $8.13^{* *}$ & $3.44 *$ & $5.69^{* *}$ & $1.88^{*}$ & 1.11 & $1.73^{*}$ \\
\hline 109 & 109 & 109 & 109 & 106 & 80 & 77 \\
\hline
\end{tabular}

Conversion premium

First issue dummy

Contamination dummy

\begin{tabular}{|c|c|c|c|c|c|c|c|}
\hline Adjusted $R^{2}$ & 0.034 & 0.062 & 0.022 & 0.042 & 0.055 & 0.007 & 0.056 \\
\hline$F$-statistic & $4.77 * *$ & $8.13^{* *}$ & $3.44 *$ & $5.69 * *$ & $1.88^{*}$ & 1.11 & $1.73^{*}$ \\
\hline Number of observations & 109 & 109 & 109 & 109 & 106 & 80 & 77 \\
\hline
\end{tabular}

Notes: Three-day $(-1,1)$ announcement-period abnormal returns are estimated using the standard market model procedure with the parameters estimated for the period 200 days to 61 days before the announcement. The revenue-based Herfindahl index is calculated as the sum of the squares of each segment's revenue as a proportion of total revenue. Tobin's $q$ is estimated as the average ratio of the market value of the firm's assets to the book value of the firm's assets for the three fiscal years before the announcement, where the market value of assets is estimated as the book value of assets minus the book value of common equity plus the market value of common equity. Debt ratio is long-term debt divided by book value of total assets for the year preceding the announcement. Volatility of earnings is the standard deviation of the announcing firm's earnings before interest and tax divided by total assets over the 5 years preceding the announcement. Firm size is the announcing firm's market value of assets for the year preceding the announcement. The relative size of the issue is the total amount of a convertible debt issue divided by the market capitalization of the issuing firm for the year preceding the announcement. Runup is the 29-day cumulative abnormal returns from 30 to 2 days preceding the announcement. Refinance dummy takes a value of 1 when convertible issues are used to refinance debt and zero otherwise. Conversion premium ratio is conversion price divided by the market price of the underlying common stock, measured by the 30-day average closing price proceeding the issue-approval date. First issue dummy equals one when the convertible debt issue is the first one and zero otherwise. A contamination dummy variable is included for those events with other contemporaneously announced information. The $t$-values in parentheses are calculated with heteroskedasticity-consistent standard errors (White, 1980).

"***", "**”, and "** represent $1 \%, 5 \%$, and $10 \%$ significance levels, respectively. The numbers of observations in models $5-7$ are smaller, because of missing data on some of the control variables. 
Firm size is included in the regression model, as a proxy for the degree of information asymmetry. Brennan and Kraus (1987), Brennan and Schwartz (1988), Constantinides and Grundy (1989), and Stein (1992) argue that convertibles are useful in mitigating the problem of information asymmetry. Since many researchers (e.g. see Kang and Stulz, 1996; Abhyankar and Dunning, 1999; Lewis et al., 1999) suggest that information asymmetry is likely to be more severe for small firms, we expect market reaction to be negatively related to firm size. We also control for the relative size of a convertible issue. Miller and Rock (1985) theoretically link issue size with the strength of a security's signal to the market, and Mikkelson and Partch (1986), Jen et al. (1997), Lewis et al. (1999), and others empirically demonstrate this link for convertible debt offerings.

Following Jen et al. (1997) and Lewis et al. (1999), we include runup, as calculated by the 29-day cumulative abnormal returns before the offering announcement, in the model in order to reveal if the size of the pre-offer stock price performance is related in any systematic way to the market's response to the announcement. A dummy variable for the stated purpose of convertible debt offerings is also included in the model since Mikkelson and Partch (1986) report that convertible debt offerings by US firms that refinance debt receive substantial negative market reactions. This refinance dummy variable takes a value of 1 when convertible issues are used to refinance debt and zero otherwise. ${ }^{20}$

We also control for the conversion premium ratio. Jen et al. (1997) use the conversion premium to measure how much of the convertible's value lies initially in it's equity or option component. They find that the stock market responds less favorably to those convertible issues that are more like equity than debt. To control for the deregulation effect as mentioned before, we have also included a first issue dummy that equals one when the convertible debt issue is the first one and zero otherwise. Finally, a "contamination dummy" is used to control for "contaminated" events where there are simultaneous announcements. ${ }^{21}$

In models 5-7, Table 5, we estimate multivariate cross-sectional regressions of the announcement-period abnormal returns controlling for these factors where the degree of corporate focus is measured by the revenue-based Herfindahl index. ${ }^{22} \mathrm{Al}-$ though not reported, our results are similar if the other three alternative measures of corporate focus are used. Model 5 includes the control variables of Tobin's $q$, debt ratio, volatility of earnings, firm size, relative size of issue, and runup, while model 6 includes the rest of the control variables. Model 7 includes all the control variables.

Results in models 5-7 are consistent with those in models 1-4. After controlling for other potentially influential factors, the sequential-financing hypothesis still holds. The coefficient for the revenue-based Herfindahl index is significantly positive. That is, convertibles are more valuable for issuing firms with focused activities than for those with less-focused activities.

\footnotetext{
${ }^{20}$ Eleven observations stated that their convertible issues were used to refinance debt.

${ }^{21}$ Forty-two observations had contemporaneous announcements.

${ }^{22}$ The numbers of observations in models 5-7 are smaller because of missing data on some of the control variables.
} 
The only control variables that are statistically significant are Tobin's $q$ and debt ratio. ${ }^{23}$ Firms with high-growth opportunities and expected costs of financial distress are found to benefit more from convertible issues. The results are consistent with Stein's (1992) backdoor-equity hypothesis. Our finding of a positive relationship between the announcement effects and Tobin's $q$ is also consistent with Mayers' (1998) sequential-financing hypothesis. Mayers' model views convertibles as a cost-effective way for firms with promising growth opportunities to finance a sequence of potential investment options. The model is only valid if firms have valuable growth opportunities. Consequently, Mayers' sequential-financing hypothesis also predicts that convertibles are more valuable for firms with high-growth opportunities. ${ }^{24}$

\section{Issuing firms net new financing over the life of convertible debt}

We also examine the issuing firms' incremental financing over the life of convertible bonds. We first compute incremental financing for each sample firm in each year from the time of convertible debt issuance to its maturity or forced conversion, where incremental financing is defined as new long-term debt and equity capital minus refinancing of existing long-term debt. The data are obtained from the TEJ Data Bank. We then compute the average and median amount of incremental financing, as well as the fraction of firms where incremental financing is non-positive, for our sample in each year prior to maturity or forced conversion of convertibles. Table 6 presents the results.

As shown in Table 6, we find that for each year following the convertible debt offerings, the mean amount of incremental financing is insignificantly different from zero prior to maturity or forced conversion. The median amount of incremental financing is always zero in each year after the convertible issues. In addition, the majority of the sample firms do not show any positive net new financing in each year prior to maturity or forced conversion. The fraction of firms where incremental financing is non-positive ranges from $50 \%$ to $81 \%$. The evidence suggests that most of the convertibles in our sample are successfully designed to avoid excess financing costs as described in the sequential-financing hypothesis.

\section{Conclusion}

The sequential-financing hypothesis advanced by Mayers (1998) suggests that convertibles are more valuable for issuing firms with focused activities. The hypothesis

\footnotetext{
${ }^{23}$ We have also looked at the residual volatility as an alternative measure of information asymmetry (as in Krishnaswami and Subramaniam, 1999). We estimate the residual volatility as the standard deviation of residuals in the market-adjusted daily returns in the year preceding the announcement of the convertible bond issue. We find that this alternative proxy for information asymmetry has no significant explanatory power and the conclusions in this study remain unchanged.

${ }^{24}$ We have also included industry dummies in the multivariate regressions to control for potential industry effects. The conclusions in this study remain unchanged.
} 
Table 6

Issuing firms' incremental financing prior to maturity or forced conversion of convertibles

\begin{tabular}{|c|c|c|c|c|c|c|c|c|c|}
\hline Years after issuance & 1 & 2 & 3 & 4 & 5 & 6 & 7 & 8 & 9 \\
\hline Number of observations & 109 & 94 & 53 & 19 & 16 & 15 & 7 & 6 & 0 \\
\hline $\begin{array}{l}\% \text { of firms with zero or negative } \\
\text { incremental financing }\end{array}$ & 72 & 73 & 72 & 68 & 81 & 67 & 57 & 50 & - \\
\hline $\begin{array}{l}\text { Mean amount of incremental } \\
\text { financing (US\$ million) }\end{array}$ & 44 & 38 & 60 & 50 & 2 & 152 & 36 & 47 & - \\
\hline$t$-Statistic & 0.35 & 0.32 & 0.25 & 0.36 & 0.26 & 0.38 & 0.54 & 0.44 & - \\
\hline $\begin{array}{l}\text { Median amount of incremental } \\
\text { financing (US\$ million) }\end{array}$ & 0 & 0 & 0 & 0 & 0 & 0 & 0 & 0 & - \\
\hline Wilcoxon $p$-value & 0.65 & 0.83 & 0.58 & 0.76 & 0.87 & 0.82 & 0.89 & 0.89 & - \\
\hline
\end{tabular}

Notes: This table presents the distribution, by year, of the firms' incremental financing from the issuance of convertible bonds to their maturity or forced conversion, where incremental financing is defined as new long-term debt and equity capital minus refinancing of existing long-term debt. The data are obtained from the TEJ Data Bank. There are 86 Taiwanese firms involved in 109 convertible debt issues from 1990 to 1999 .

also suggests that firms may design the convertibles so that there are sufficient internal funds for future investment expenditures so as to avoid the costs of accessing capital markets. This paper provides direct evidence for these two predictions using a sample of convertible issues by Taiwanese firms.

The use of Taiwanese data in this study provides important international evidence and adds to our understanding of issues relevant in different business environments. Capital markets in countries on the Pacific Rim have attracted increasing attention from both practitioners and researchers, and Taiwan is an excellent representative of one of the fastest-growing economies in this region. This paper thus provides useful insights into the determinants of the stock market response to announcements of convertible issues by firms in high-growth economies. Therefore, our results on the Meyers model are generalizable over other fast-growing economies, such as Hong Kong, South Korea, and Singapore. The results in this paper are also generalizable over the developed economies, such as the United States and the United Kingdom. The use of Taiwanese data in this study helps examine the sequential-financing hypothesis since the cost-controlling function of convertibles is particularly valuable for growth firms with uncertain future investment options. Therefore, our results on the Meyers model may be applicable to those high-growth firms in the developed economies.

In this paper we find that announcements of convertible debt offerings by Taiwanese firms are, on average, associated with significantly positive abnormal returns. We also find that the stock market responds more favorably to the announcements of convertible offerings by focused firms than to those by diversified firms. This finding holds even after controlling for other potential explanatory variables. We also show that the issuing firms' net new financing is not significantly different from zero over the life of the convertible debt. Thus, our results provide further support for the sequential-financing hypothesis that convertible debt financing is motivated by a desire to minimize security issue costs and agency costs of overinvestment for firms with 
promising growth opportunities to finance a sequence of major corporate investments of uncertain value and timing.

\section{Acknowledgements}

The authors wish to thank Konan Chan, Frank Jen, Timo Korkeamaki, Chengfew Lee, Jai Woong Lee, and especially two anonymous referees for helpful comments and suggestions. This paper has been benefited from comments by the seminar participants at the 2001 FMA European Conference, the Tenth Conference on the Theories and Practices of Securities and Financial Markets, and the 2002 Academic Conference of Taiwan Finance Association. Any remaining errors are the authors'. Shao-Chi Chang acknowledges funding from the National Science Council in Taiwan (NSC90-2416-H006-007).

\section{References}

Abhyankar, A., Dunning, A., 1999. Wealth effects of convertible bond and convertible preference share issues: An empirical analysis of the UK market. Journal of Banking and Finance 23, 1043-1065.

Agrawal, A., Knoeber, C.R., 1996. Firm performance and mechanisms to control agency problems between managers and shareholders. Journal of Financial and Quantitative Analysis 31, 377-397.

Anderson, R.C., Bates, T.W., Bizjak, J.M., Lemmon, M.L., 2000. Corporate governance and firm diversification. Financial Management 29, 5-22.

Barclay, M.J., Smith Jr., C.W., 1995a. The maturity structure of corporate debt. Journal of Finance 50, 609-631.

Barclay, M.J., Smith Jr., C.W., 1995b. The priority structure of corporate liabilities. Journal of Finance 50, 899-917.

Barclay, M.J., Litzenberger, R., 1988. Announcement effects of new equity issues and the use of intraday price data. Journal of Financial Economics 21, 71-100.

Berger, P.G., Ofek, E., 1995. Diversification's effect on firm value. Journal of Financial Economics 37, 3966.

Brennan, M., Kraus, A., 1987. Efficient financing under asymmetric information. Journal of Finance 42, 1225-1243.

Brennan, M., Schwartz, E., 1988. The case for convertibles. Journal of Applied Corporate Finance 1, 5564.

Chen, S.S., Ho, K.W., 1997. Market response to product-strategy and capital-expenditure announcements in Singapore: Investment opportunities and free cash flow. Financial Management 26, 82-88.

Chen, S.S., Ho, K.W., Lee, C., Yeo, G.H.H., 2000. Investment opportunities, free cash flow and market reaction to international joint ventures. Journal of Banking and Finance 24, 1747-1765.

Chung, K.H., Pruitt, S.W., 1994. Simple approximation of Tobin's $q$. Financial Management 23, 70-74.

Comment, R., Jarrell, G.A., 1995. Corporate focus and stock returns. Journal of Financial Economics $37,67-87$.

Constantinides, G., Grundy, B., 1989. Optimal investment with stock repurchase and financing as signals. Review of Financial Studies 2, 445-465.

Dann, L., Mikkelson, W., 1984. Convertible debt issuance, capital structure change and financing-related information. Journal of Financial Economics 13, 157-186.

Davidson, W.N., Glascock, J.L., Schwartz, T.V., 1995. Signaling with convertible debt. Journal of Financial and Quantitative Analysis 30, 425-440. 
Denis, D., 1994. Investment opportunities and the market reaction to equity offerings. Journal of Financial and Quantitative Analysis 29, 159-178.

Denis, D., Denis, D., Sarin, A., 1997. Agency problems, equity ownership, and corporate diversification. Journal of Finance 52,, 135-160.

De Roon, F., Veld, C., 1998. Announcement effects of convertible bond loans and warrant-bond loans: An empirical analysis for the Dutch market. Journal of Banking and Finance 22, 1481-1506.

Dodd, P., Warner, J.B., 1983. On corporate governance: A study of proxy contests. Journal of Financial Economics 11, 401-438.

Doukas, J., 1995. Overinvestment, Tobin's $q$ and gains from foreign acquisitions. Journal of Banking and Finance 19, 1285-1303.

Eckbo, B.E., 1986. Valuation effects of corporate debt offerings. Journal of Financial Economics 15, 119151.

Essig, S., 1991. Convertible securities and capital structure determinants. Ph.D. dissertation. Graduate School of Business, University of Chicago, Chicago, IL.

Green, R., 1984. Investment incentives, debt and warrants. Journal of Financial Economics 13, 115136.

Hansen, R., Crutchley, C., 1990. Corporate earnings and financings: An empirical analysis. Journal of Business 63, 347-372.

Holderness, C.G., Kroszner, R.S., Sheehan, D.P., 1999. Were the good old days that good? Changes in managerial stock ownership since the Great Depression. Journal of Finance 54, 435-469.

Hoshi, T., Scharfstein, D., Kashyap, A.K., 1993. The choice between public and private debt: An analysis of post-deregulation corporate financing in Japan. NBER Working Paper \#4421.

Howe, K.M., He, J., Kao, G.W., 1992. One-time cash flow announcements and free cash-flow theory: Share repurchase and special dividends. Journal of Finance 47, 1963-1975.

Jen, F.C., Choi, D., Lee, S.H., 1997. Some new evidence on why companies use convertible bonds. Journal of Applied Corporate Finance 10, 44-53.

Jensen, M.C., 1986. Agency costs of free cash flow, corporate finance, and the market for takeovers. American Economic Review 76, 323-329.

Jensen, M.C., Meckling, W., 1976. Theory of the firm: Managerial behavior, agency costs and ownership structure. Journal of Financial Economics 3, 305-360.

Kang, J.K., Stulz, R.M., 1996. How different is Japanese corporate finance? An investigation of the information content of new security issues. Review of Financial Studies 9, 109-139.

Kim, Y.C., Stulz, R.M., 1992. Is there a global market for convertible bonds? Journal of Business 65, 75 91.

Krishnaswami, S., Subramaniam, V., 1999. Information asymmetry, valuation, and the corporate spin-off decision. Journal of Financial Economics 53, 73-112.

Lang, L.P.H., Litzenberger, R., 1989. Dividend announcements: Cash flow signalling vs. free cash flow hypothesis? Journal of Financial Economics 24, 181-192.

Lang, L.H.P., Stulz, R.M., Walkling, R.A., 1989. Managerial performance, Tobin's $Q$, and the gains from successful tender offers. Journal of Financial Economics 24, 137-154.

Lang, L.H.P., Stulz, R.M., Walkling, R.A., 1991. A test of the free cash flow hypothesis: The case of bidder returns. Journal of Financial Economics 29, 315-335.

Lewis, C.M., Rogalski, R.J., Seward, J.K., 1998. Agency problems, information asymmetries, and convertible debt security design. Journal of Financial Intermediation 7, 32-59.

Lewis, C.M., Rogalski, R.J., Seward, J.K., 1999. Is convertible debt a substitute for straight debt or for common equity? Financial Management 28, 5-27.

Lindenberg, E., Ross, S., 1981. Tobin's $q$ ratio and industrial organization. Journal of Business 54, 1-32.

Mayers, D., 1998. Why firms issue convertible bonds: The matching of financial and real investment options. Journal of Financial Economics 47, 83-102.

Mikkelson, W., Partch, M., 1986. Valuation effects of security offerings and the issuance process. Journal of Financial Economics 15, 31-60.

Miller, M., Rock, K., 1985. Dividend policy under asymmetric information. Journal of Finance 40, 10311052. 
Myers, S., 1977. Determinants of corporate borrowing. Journal of Financial Economics 5, 147-175.

Perfect, S.B., Wiles, K.W., 1994. Alternative constructions of Tobin's $q$ : An empirical comparison. Journal of Empirical Finance 1, 313-341.

Rose, N.L., Shepard, A., 1997. Firm diversification and CEO compensation: Managerial ability or executive entrenchment? Rand Journal of Economics 28, 489-514.

Stein, J.C., 1992. Convertible bonds as backdoor equity financing. Journal of Financial Economics 32, 3 21.

White, H., 1980. A heteroskedasticity-consistent covariance matrix estimator and a direct test for heteroskedasticity. Econometrica 48, 817-838. 